\title{
THE INFLUENCE OF METACOGNITIVE LEARNING STRATEGIES ON SELF-ASSESSMENT LEVEL OF SECONDARY SCHOOL PUPILS
}

\author{
[VPLYV METAKOGNITIVNYCH STRATEGII UCENIA NA \\ UROVEN SEBAHODNOTENIA SKOLSKEHO VYKONU ZIAKOV \\ STREDNYCH SKOL]
}

\author{
Juraj Komora - Katarina Vyrostekova
}

\section{doi: 10.18355/PG.2016.5.1.174-183}

\begin{abstract}
The effectiveness of the educational process is conditioned by many factors such as pupils' motivation to learning, choice of learning strategies, anxiety, fear, self-confidence, self-esteem level in school performance of pupils, the use of critical thinking, and level of metacognition development, metacognitive processes. Metacognition as a conscious activity caused by a subjective awareness of own thinking processes, ways of learning (teaching), ability to manipulate own cognitive processes and metacognitive regulation (planning, monitoring, evaluation) and controlling of behaviour; is considered one of the key components of effective learning (teaching). This is now the most studied concept of psychological research (in Ontogenetic Psychology, Psychology of Teaching, Educational Psychology) and gets to the fore in educational research, too (in the field of metacognitive processes development in reading comprehension, the development of metacognitive potential by the different procedures, methods and drills, and metacognitive monitoring pre-knowledge and knowledge base of the students).
\end{abstract}

\section{Keywords}

self assessment, metacognition, metacognitive processes, the effectiveness of the educational process

\begin{abstract}
Abstrakt
Efektívnost' výchovno-vzdelávacieho procesu je podmienená mnohými faktormi ako napr. motiváciou žiakov $\mathrm{k}$ učeniu, výberom stratégii učenia, úzkost'ou, strachom, sebadôverou, úrovňou sebahodnotenia školského výkonu žiakov, využívaním kritického myslenia, alebo úrovňou rozvoja metakognície, metakognitívnych procesov. Metakognícia ako vedomá činnost' vyvolaná subjektívnym uvedomovaním si vlastných myšlienkových procesov, spôsobov učenia (sa), schopnosti manipulovat' s vlastnými kognitívnymi procesmi a metakognitívnou reguláciou (plánovaním, monitorovaním, hodnotením) a kontrola spávania, sa považuje za jednu z kl’účových komponentov efektívneho učenia (sa). Stáva sa v súčasnosti najviac študovaným konceptom v psychologickom
\end{abstract}


výskume (v ontogenetickej psychológii, psychológii vyučovania, pedagogickej psychológii) a dostáva sa do popredia aj v pedagogickom výskume (v oblasti rozvoja metakognitívnych procesov pri porozumení textov; rozvoja metakognitívneho potenciálu na základe rôznych postupov, metód a nácvikov a metakognitívnym monitorovaním predvedomostívedomostnej základne študentov).

\section{Kl'účové slová}

sebahodnotenie, metakognícia, metakognitívne procesy, efektívnost' výchovno-vzdelávacieho procesu

\section{Úvod}

Pojem metakognícia ako taký, sa dostáva do povedomia pedagógov a psychológov pomerne často, a je predmetom viacerých odborných diskusií v oblasti edukácie, hlavne v oblasti zvyšovania efektívnosti vo výchovno-vzdelávacom procese. S tým je úzko spojená požiadavka na učitel'ov, aby aplikovali metakognitívne stratégie učenia na rozvoj metakognície u žiakov. Zároveň sa apeluje na žiaka, aby si osvojil tieto učebné stratégie a následne rozvíjal svoju metakogníciu.

\section{Teoretické východiská riešeného problému}

Základným konceptom metakognície, ktorý sa dodnes uvádza vo svojej takmer pôvodnej podobe, je model kognitívneho monitoringu (metakognitívne vedomosti, metakognitívna regulácia a metakognitívne presvedčenie), ktorý rozpracoval P. R. Simons (1994a,b) inšpirovaný prácami mnohých autorov (napr. A. L. Brown 1981; J. H. Flavell 1979; a d'alší). Od 70. rokov 20. storočia sa problematikou metakognície zaoberalo množstvo autorov a v súčasnosti môžeme povedat', že sa stala samozrejmou súčast'ou konceptov spájaných so zvyšovaním efektívnosti procesov učenia sa žiakov.

Ked'že ciel'om tejto štúdie nie je analýza jednotlivých teórií metakognície, budeme sa venovat' výhradne len tej časti problematiky, ktorá je zameraná na vplyv metakognitívnych stratégií na úroveň sebahodnotenia školského výkonu žiakov.

Metakognitívne stratégie učenia sú najčastejšie označované za procesy, v ktorých subjekt reflektuje vlastné kognitívne postupy a z určitej „metaúrovne“ ich plánuje, kontroluje, hodnotí, komentuje a pod. Okrem kognitívnych postupov sa sem zarad'ujú aj metakognitívne poznatky o úlohe či probléme a metakognitívne poznatky o vlastnej osobe (Hnilica, 1992: 481).

Ako uvádzajú autori J. Skoda. a P. Doulik (2011: 63), žiaci nie sú často vedení k uvedomovaniu si vlastných myšlienkových krokov a operácií, a nie sú vedení k pochopeniu týchto krokov. Tým sa celý proces učenia schematizuje a získava tak nežiaducu podobu univerzálne platného lineárneho algoritmu. Proces riešenia problému potom žiaci nechápu ako kreatívny proces využívania rôznych poznatkov, ale skôr ako proces 
pasívnej aplikácie určitých algoritmických postupov. Preto je potrebné zmenit' tento nežiaduci stav, ktorý nenapomáha efektívnosti výchovnovzdelávacieho procesu, ani nerozvíja aktívne učenie. Práve naopak, podporuje učenie mechanické (napr. učenie sa naspamät' bez porozumenia toho, čo som sa práve naučil).

To je dôvod, prečo by sa mali učitelia viac snažit' o aplikáciu metakognitívnych stratégií do vyučovania s ciel'om rozvíjat' metakogníciu u svojich žiakov a tým zefektívňovat' ich proces učenia sa. Uvedomovanie si svojich schopností je začiatkom metakognitívneho spracovania informácií. Ich uplatnenie vidíme aj v reagovaní na seba samého, kedy žiak hl'adá optimálne spôsoby reagovania na prostredie a snaží sa zdokonalit' svoje poznávacie procesy. Metakognitívnymi stratégiami, sa žiaci naučia efektívne využívat' postupy riešenia úloh, rýchlejšie nájst' ten najvhodnejší spôsob reagovania na prostredie, lepšie mysliet', úspešnejšie sa učit'. Naučia sa nielen „poznávat', ako vlastne poznávajú“, ale taktiež sa naučia usmerňovat' a riadit' vlastné poznávacie procesy, a využívat' metakognitívnu reguláciu (executive control) v procese učenia, ktorá sa skladá z troch základných etáp - plánovanie (planning), monitorovanie (monitoring) a hodnotenie (evaluating). Uvažovanie nad vlastnými kognitívnymi procesmi posilní sebaistotu žiaka $\mathrm{v}$ jeho výkonoch a taktiež stabilnejšie sebahodnotenie. (Vyrostekova, 2012)

Výskumný program zaoberajúci sa metakognitívnym monitorovaním predvedomostí (vedomostnej základne) realizovaný autormi S. Tobias a $\mathrm{H}$.

T. Everson (In Hacker, D., J., Dunlosky, J., Graesser, A., C., 2009: 108 109), bol založený na správnom hodnotení vlastných vedomostí. Spomínaní autori zist'ovali, nakol'ko študenti dokážu rozlíšit' to čo vedia alebo čo sa už predtým naučili od toho, čo nevedia alebo potrebujú vediet' a tým si môžu zvolit' a použit' zložitejšie metakognitívne stratégie učenia. Dospeli k záverom, že ak žiaci správne hodnotili vlastné vedomosti (metakognitívnym monitorovaním predvedomostí) dokázali rozoznat' čo vedia od toho čo nevedia a používali zložitejšie metakognitívne stratégie učenia. Správne hodnotenie vlastných vedomostí bolo podmienené reálnym sebahodnotením, ktoré záviselo od úrovne rozvoja metakognície. Žiaci s nízkou úrovňou metakognície nerealizovali metakognitívny monitoring predvedomostí, mali skreslené hodnotenie vlastných vedomostí, a boli často s učivom pozadu. Namiesto toho, aby sa učili neznáme učivo alebo zvládli nové učivo, strácali čas s už známym učivom. Mnohí autori zdôrazňujú (Flavell, 1979; Brown, 1980; Duchovicova, 2013; Babulicova, 2013), že všetky tri zložky metakognície (vedomosti o metakognícii, schopnost' sledovat' a monitorovat' procesy učenia jednotlivca, kontrola a hodnotenie procesov učenia) sú potrebné na efektívnu a účinnú reguláciu učenia. Hodnotenie procesov učenia v sebe zahŕňa samozrejme správne hodnotenie vlastných vedomostí, ktoré je pre efektívnost' výchovno-vzdelávacieho procesu nemenej dôležité ako ostatné zložky metakognície. Aby žiak vedel správne hodnotit' úroveň vlastných vedomostí (schopnost' študenta sledovat' svoj stav vedomostí, svoje študijné pokroky, motiváciu, úzkost', autoreguláciu učenia, metakognitívne procesy), musí byt' jeho metakognícia rozvinutá. Metakognitívne koncipovanou výučbou, ktorá je založená aj na 
aplikácii metakognitívnych stratégii učenia, učitel' demonštruje svoje vlastné procesy myslenia a ovplyvňuje tak žiakov, aby aktivovali svoje vlastné konštruktívne myslenie. Dochádza k osvojovaniu si metakognitívnych stratégii učenia, k rozvoju metakognície a metakognitívnych procesov, ktoré sú dôležité pre správne hodnotenie úrovne vlastných vedomostí a primeranej úrovne sebahodnotenia školského výkonu. Prostredníctvom metakognitívnych stratégii učenia žiak reflektuje nielen kognitívne procesy (ktoré z určitej „metaúrovne“ plánuje, monitoruje, kontroluje, hodnotí, komentuje a pod.), ale aj metakognitívne poznatky o úlohe, probléme, situácii a vlastnej osobe. (Hnilica, 1992: 481)

Vzájomný vzt’ah sebahodnotenia a metakognície preukazuje aj triadická teória autoregulácie od B. Zimmermana (1990: 6-7), v ktorej prepája dve teórie - sociálne kognitívnu teóriu učenia (A. Bandura) a teóriu o autoregulácii osobnosti (Thoresen a Mahoney). Vytvára tri základné subsystémy, z ktorých vychádzajú tri typy autoregulácie:

a) subsystém osobnost' jednotlivca - typ autoregulácie: vnútorná autoregulácia

b) subsystém správanie jednotlivca a jeho konania - typ autoregulácie: autoregulácia správania

c) subsystém vonkajšie prostredie $v$ ktorom sa jednotlivec nachádza typ autoregulácie: autoregulácia prostredia.

Ich podstata spočíva v nasledovnom (Mareš, 1998: 177):

- Vnútorná autoregulácia - ide o autoreguláciu, pri ktorej jednotlivec riadi sám seba, svoju osobnost'. Pri autoregulácii osobnosti jednotlivca je vel'mi dôležitá sebapercepcia. Sebapercepciu ovplyvňujú prinajmenšom štyri faktory: znalosti žiaka (deklaratívne, procedurálne, kontextové, autoregulačné), metakognitívne procesy žiaka (metakognitívne vedomosti, metakognitívne presvedčenie a metakognitívna regulácia - plánovanie, monitorovanie, hodnotenie), ciele žiaka (krátkodobé aj dlhodobé) a afektívne procesy žiaka (strach, úzkost', smútok, radost' a pod.).

- Autoregulácia správania - pre správanie a konanie jednotlivca sú dôležité tri premenné. Ide o sebapozorovanie žiaka (o jeho introspekcii sa môžeme dozvediet' napr. z hovoreného slova alebo písomného záznamu, z jeho evidovania vlastných chýb, z poznámok o svojom výkone a pod.); sebahodnotenie žiaka (skúmanie svojho konania; kontrolovanie svojich činností; hodnotenie svojich výsledkov vzhl'adom k stanoveným ciel'om, $\mathrm{k}$ štandardom a vzhl'adom k iným osobám) - žiak pri sebahodnotení taktiež hodnotí svoje všeobecné aj špeciálne učebné schopnosti, svoju výkonnost' v jednotlivých predmetoch, svoje postavenie $\mathrm{v}$ školskej práci v porovnaní s rovesníkmi, čo tvorí základ, svoju úspešnost' v triede, ale aj strach zo školy, čo tvorí základ sebahodnotenia školského výkonu žiaka ; reagovanie na seba samého (sebamonitorovanie, snaha zdokonalit' svoje poznávacie procesy, hl'adat' optimálne spôsoby reagovania na prostredie, v ktorom sa žiak nachádza). 
- Autoregulácia prostredia - sociálne prostredie, ktoré obklopuje žiaka, môže mat' rôznorodú podobu. Bud' sa jedná o priame skúsenosti (zážitky), alebo ide o imitáciu vzorov (priame vzory ako je žiak, učitel', rodič; symbolické vzory, ktoré sú prítomné len sprostredkovane hrdina, idol, prozaickejšie vzory ako súbor pokynov, heuristický návod, podrobný algoritmus a pod.), presviedčanie seba samého (kedy žiak nezasahuje do prostredia, ale mení svoj postoj k prostrediu) alebo naopak štruktúrovanie kontextu učenia (kedy žiak upravuje prostredie, zasahuje do situácie, úloh a pod.).

V spojitosti so sebahodnotením školského výkonu sa najviac približuje z triadickej teórie autoregulácie - druhý typ autoregulácie - autoregulácia správania. To, ako sa žiak hodnotí, hodnotí svoj výkon, svoje postavenie, ktoré má na základe toho ako hodnotia jeho učebný výkon učitelia alebo žiaci, ovplyvňuje aj jeho sebahodnotenie školskej úspešnosti.

Z nášho pohl'adu žiak, ktorý pozná svoje možnosti a schopnosti, vie čo dokáže a v čom má naopak nedostatky, vie si stanovit' primerané ašpirácie zodpovedajúce jeho potenciálu, vie si vybrat' tie najvhodnejšie stratégie učenia, ktoré mu pomôžu dosiahnut' svoj ciel' a dosahovat' v školskej práci úspešné výkony. Má mieru sebadôvery na primeranej úrovni a od tejto úrovne sa odvíja aj úroveň jeho sebahodnotenia. Skôr ako si však žiak zvolí vhodnú stratégiu učenia, musí monitorovat' svoje vedomosti. Teda správne sledovat' kognitívne procesy. Bez toho, aby žiaci vedeli čo už vedia alebo ešte nevedia, čo už zvládli alebo ešte nezvládli, nemôžu realizovat' metakognitívne procesy ako plánovanie, hodnotenie alebo výber stratégii učenia. Preto metakognitívne stratégie učenia a ich implementácia do výchovno-vzdelávacieho procesu (kedy sám učitel' využíva metakognitívne stratégie a sám využíva metakogníciu) pomôže žiakom osvojit' si tieto stratégie, monitorovat' svoje kognitívne procesy a následne ich využívat'. Tie mu umožnia lepšie a efektívnejšie riešit úlohy, problémy, a tak dosahovat' lepšie výkony v škole. To posilňuje sebadôveru žiaka a v konečnom dôsledku aj jeho sebahodnotenie. (Vyrostekova, 2012).

\section{Výskumný problém}

Vzt’ah metakognície, metakognitívnych stratégii a sebahodnotenia žiaka bol prezentovaný $\mathrm{v}$ rámci rôznych teórií. No z nám dostupných výskumov zatial' ani jeden nepreukázal, nakol'ko metakognícia, metakognitívne stratégie učenia, ovplyvňujú sebahodnotenie školského výkonu žiakov, či skutočne používanie metakognitívnych stratégií učenia zásadným spôsobom zvyšuje úroveň sebahodnotenia školského výkonu u žiakov. Preto sme si náš výskumný problém formulovali nasledovne: do akej miery metakognitívne stratégie učenia ovplyvnia úroven̆ sebahodnotenie školského výkonu žiakov SŠ?

V nadväznosti na stanovený výskumný problém, sme si zadefinovali ciel' výskumu: analyzovat' vplyv metakognitívnych stratégii učenia implementovaných do výchovno-vzdelávacieho procesu na sebahodnotenie školského výkonu žiakov Š̆.

$\mathrm{Na}$ základe takto konkretizovaného ciel’a sme následne formulovali hypotézu: predpokladáme rozdiel v sebahodnotení školského výkonu 
žiakov SŠ medzi experimentálnou a kontrolnou skupinou po aplikácii metakognitívnych stratégií učenia.

\section{Výber vzorky}

Výskumný súbor tvorilo spolu 105 žiakov SSOŠ. Z toho experimentálnu skupinu nám tvorilo 53 žiakov a kontrolnú 52 žiakov SSOŠ, pričom bol uplatnený zámerný výber.

Metódy skúmania: $Z$ uvedeného vyplýva, že jednou z metód pri získavaní potrebných údajov $\mathrm{v}$ rámci nášho skúmania bol experiment. Jednalo sa o prirodzený experiment, pričom $\mathrm{v}$ experimentálnej skupine sme manipulovali s nezávislou premennou (metakognitívnymi stratégiami učenia). Experiment dopíňalo dlhodobé pozorovanie.

$\mathrm{Na}$ zistovanie úrovne sebahodnotenia sme použili dotazník sebahodnotenia školskej úrovne a vzt’ahu ku škole, ktorý ponúka komparáciu sebahodnotenia žiaka a hodnotenia žiaka rodičmi alebo učitel'om. Bol vypracovaný na základe už známych metód sebahodnotenia diet’at’a (SPAS - dotazník sebapojatia školskej úspešnosti diet’ata). Je možné ho použit' individuálne ale aj skupinovo a obsahuje 15 položiek, ktoré boli na základe faktorovej analýzy rozdelené na tri subškály (Vagnerova, 2008: 411-414) :

- Sebahodnotenie školskej práce a miera jej zvládania - napr. položka č. 3. , Unavuje ma, ked' musím nad úlohou velmi rozmýšl'at."

- Sebahodnotenie relatívnej úspešnosti v triede $\mathrm{v}$ porovnaní s ostatnými det’mi - napr. položka č. 9. „Väčšina mojich spolužiakov sa v triede učí lepšie ako ja."

- Strach zo školy - napr. položka č. 14. „Ústne skúšanie pred celou triedou ma znervózñuje."

Údaje sme spracovali štatistickým programom SPSS (Statistical Package for Social Sciences), v ktorom sme použili konkrétne tieto metódy:

- Koeficient šikmosti (Skewness) a Koeficient strmosti (Kurtosis) štatistické ukazovatele tvaru distribúcie, ktoré nám na základe koeficientov (menšie alebo väčšie ako 1) určujú, či empirické údaje dovol'ujú použit' pri komparácii parametrický test. Nakol'ko distribúcie nami skúmaných premenných $\mathrm{v}$ oboch podsúboroch boli jednovrcholové, koeficienty šikmosti a strmosti boli menšie ako 1 a premenné mali približne normálne rozloženie, používali sme na štatistické spracovanie výskumných údajov (komparáciou) parametrické testy.

- Studentov t-test pre dva nezávislé výbery (Independent Samples T Test), týmto testom sme zist'ovali štatistickú hladinu významnosti rozdielu v úrovni sebahodnotenia školského výkonu žiakov medzi kontrolnou a experimentálnou skupinou pred aj po aplikácii metakognitívnych stratégii učenia.

\section{Analýza získaných údajov}


Na základe výskumných zistení od autorov S. Tobias a H. T. Everson (In Hacker, Dunlosky, Graesser, 2009: 108-109) v oblasti metakognitívneho monitoringu predvedomostí a správneho hodnotenia vlastných vedomostí a triadickej teórie autoregulácie B. Zimmermana (1990: 6-7) sme predpokladali vplyv metakognitívnych stratégii učenia na sebahodnotenie školského výkonu žiakov. Konkrétne sme predpokladali, že nami aplikovanými stratégiami učenia (SQ4R, MURDER, think-along a metódou vzoru kognitívnej činnosti) do výchovno-vzdelávacieho procesu ovplyvníme úroveň sebahodnotenia školského výkonu žiakov. Preto sme následne predpokladali rozdiel v sebahodnotení školského výkonu žiakov medzi experimentálnou a kontrolnou skupinou po aplikácii metakognitívnych stratégii učenia.

Komparáciu dvoch skupín (kontrolná, experimentálna) podl’a kvantitatívnej premennej (sebahodnotenie školského výkonu žiakov) sme riešili v SPSS programe, pričom testovacím kritériom bol Studentov t-test pre dva nezávisle výbery. Skôr ako sme si zvolili testovacie kritérium, sme štatistickou deskripciou zist'ovali distribúciu skúmanej premennej v oboch podsúboroch. Distribúcia skúmanej premennej v oboch podsúboroch bola jednovrcholová. Koeficienty šikmosti a strmosti boli menšie ako 1 . Premenná mala približne normálne rozloženie, čo znamenalo, že sme mohli v analýze používat' numerické charakteristiky ako sú priemer a štandardnú odchýlku a umožnilo nám to pri komparácii použit' už spomínaný parametrický test.

Štatistickú hladinu významnosti rozdielu v sebahodnotení školského výkonu žiakov medzi kontrolnou a experimentálnou skupinou sme zaznamenali (tabul'ka 1). Hodnota signifikancie nižšia než stanovená hladina významnosti $\alpha=5 \%$ bola zaznamenaná medzi premennými, kde $\mathrm{p}$ $<$ 0,05. Ako z tabul'ky vyplýva, hodnota Studentovho t-testu pri 103 stupňoch vol'nosti je $-0,639$ a dosiahnutá signifikancia má hodnotu nižšiu ako $0,05 \quad\left(\mathrm{t}_{(103)}=-0,639 ; \mathrm{p}<0,05\right)$. Rozdiel $\mathrm{v}$ úrovni sebahodnotenia školského výkonu žiakov je s 95-percentnou pravdepodobnost'ou $\mathrm{v}$ intervale $(-2,4298 ; 1,2455)$ bodu.

Tabul'ka 1 Rozdiel v sebahodnotení školského výkonu žiakov medzi kontrolnou a experimentálnou skupinou po aplikácii metakognitívnych stratégii učenia

\begin{tabular}{|c|c|c|c|c|c|c|}
\hline \multicolumn{7}{|c|}{ Rozdiel v sebahodnotení školského výkonu žiakov } \\
\hline Stav & Skupina & Početnost' & AM & SD & t & Sig. \\
\hline \multirow{2}{*}{$\begin{array}{c}\text { Pred } \\
\text { aplikáciou }\end{array}$} & Kontrolná & 52 & 15,6923 & 4,386 & 1,241 & 0,483 \\
\cline { 2 - 7 } $\begin{array}{c}\text { Po } \\
\text { aplikácii }\end{array}$ & Experimentálna & 53 & 14,5849 & 4,7452 & & \\
\cline { 2 - 7 } & Kxperimentálna & 53 & 16,6154 & 4,0008 & $-0,639$ & 0,030 \\
\hline
\end{tabular}

$\mathbf{A M}=$ aritmetický priemer, $\mathbf{S D}=$ standardná odchýlka, $\mathbf{t}=$ testovacia hladina, $\mathbf{S i g} .=$ hodnota dosiahnutej signifikancie/významnosti $p<0.05$

Na základe výskumných zistení môžeme teda potvrdit', že existuje rozdiel v sebahodnotení školského výkonu žiakov medzi kontrolnou a experimentálnou skupinou po aplikácii metakognitívnych stratégii učenia, 
pričom žiaci v experimentálnej skupine dosahovali vyššiu úroveň sebahodnotenia školského výkonu ako žiaci v kontrolnej skupine. Zmenu v úrovni sebahodnotenia školského výkonu žiakov v experimentálnej skupine potvrdzuje aj tabul'ka 2, ktorá vyjadruje percentuálne zastúpenie zvýšenia alebo poklesu úrovne sebahodnotenia školského výkonu žiakov pred a po aplikácii metakognitívnych stratégii učenia.

Tabul'ka 2 Percentuálne vyjadrenie zvýšenia alebo poklesu úrovne sebahodnotenia školského výkonu žiakov pred a po aplikácii metakognitívnych stratégii učenia

\begin{tabular}{|c|c|c|c|}
\hline \multicolumn{4}{|c|}{$\begin{array}{l}\text { Úroveň sebahodnotenia školského výkonu žiakov } \\
\text { pred a po aplikácii MSU v experimentálnej skupine }\end{array}$} \\
\hline Stav & Úroveň & $\begin{array}{c}\text { Počet žiakov } \\
\text { v \% }\end{array}$ & $\begin{array}{c}\text { Zvýšenie alebo pokles } \\
\text { úrovne v \% }\end{array}$ \\
\hline Pred apl. & \multirow{2}{*}{ vyššia } & 47,17 & \multirow{2}{*}{18,87} \\
\hline Po apl. & & 66,04 & \\
\hline Pred apl. & \multirow{2}{*}{ nižšia } & 52,83 & \multirow[b]{2}{*}{$-13,21$} \\
\hline Po apl. & & 33,96 & \\
\hline
\end{tabular}

Údaje doplňuje aj tabul'ka 3, ktorá vyjadruje percentuálne zastúpenie zvýšenia alebo poklesu úrovne všeobecnej úspešnosti žiakov pred a po aplikácii spomínaných stratégií $\mathrm{v}$ experimentálnej skupine (v úrovni všeobecnej úspešnosti žiaci dosahovali vyššiu úroveň ako v sebahodnotení školského výkonu žiakov pred aplikáciou metakognitívnych stratégii učenia. Celkový posun v úrovni nebol až tak výrazný ako v sebahodnotení školského výkonu žiakov).

Tabul'ka 3 Percentuálne vyjadrenie zvýšenia alebo poklesu úrovne všeobecnej úspešnosti žiakov pred a po aplikácii metakognitívnych stratégii učenia

\begin{tabular}{|c|c|c|c|}
\hline & $\begin{array}{r}\text { Úro } \\
\text { d a po a] }\end{array}$ & $\begin{array}{l}\text { eobecnej úspe } \\
\text { ii MSU v expe }\end{array}$ & $\begin{array}{l}\text { akov } \\
\text { Inej skupine }\end{array}$ \\
\hline Stav & Úroveň & $\begin{array}{c}\text { Počet žiakov } \\
\text { v \% }\end{array}$ & $\begin{array}{l}\text { Zvýšenie alebo pokles } \\
\text { úrovne v \% }\end{array}$ \\
\hline Pred apl. & \multirow{2}{*}{ vyššia } & 81,13 & \multirow{2}{*}{11,32} \\
\hline Po apl. & & 92,45 & \\
\hline Pred apl. & \multirow{2}{*}{ nižšia } & 18,87 & \multirow{2}{*}{$-11,33$} \\
\hline Po apl. & & 7,54 & \\
\hline
\end{tabular}

Mnoho učitel'ov nevedie žiakov k uvedomovaniu si vlastných myšlienkových krokov, postupov a kognitívnych operácií, z čoho vyplýva, že ani nemôžu viest' žiakov k pochopeniu týchto krokov. Nerozvíjajú užiakov metakogníciu, metakognitívnu reguláciu (plánovanie, monitorovanie vlastných vedomostí a postupov, hodnotenie), 
metakognitívne spracovávanie informácii a metakognitívne stratégie učenia vo výchovno-vzdelávacom procese absentujú.

Podl'a J. Skodu a P. Doulika (2011: 63) je metakognitívne koncipovaná výučba, využívanie vyučovacích metakognitívnych stratégií a celkovo metakognícia $v$ pedagogickej praxi podceňovaná. Ponechávame žiakov, aby si na základe vlastných skúseností osvojovali metakognitívne stratégie. Zabúdame však na fakt, že u mnohých žiakov nedochádza k spontánnemu, intuitívnemu osvojeniu metakognitívnych stratégií a preto je dôležitý skôr explicitný spôsob osvojenia. Teda v procese strategickej výučby, kde je potrebné viest' žiaka k otázkam, čo má robit' so svojim poznávacím „aparátom“, aby bol dobrým nástrojom úspešnej realizácie poznávacieho úsilia. Rola učitel'a tým vôbec neklesá, práve naopak. Od učitel'a sa žiak naučí aktívnemu, reflektujúcemu a tvorivému vzt'ahu k sebe samému ako k subjektu poznávania a regulovania vlastného učenia.

\section{Bibliographic references}

BAULICOVA, Z. 2013. Uroven kognicie a moznosti jej rozvijania. Rozvoj (meta)kognitivnych funkcii pri praci s chybou. In Duchovicova, J. - Skoda, J. 2013. Psychodidakticke pojeti kulikuralniho a mediacneho kontextu edukace. Usti nad Labem: UJEP. ISBN 978-80-7414-658-9.

BROWN, A. L. 1981. Knowing when, where and how to remember : A problem of metacognition. In R. Glaser (Ed.) : Advances in instructional psychology. Hillsdale, NJ : Erlbaum, vol. 1, pp. 77-165.

DUCHOVICOVA, J. 2013. Psychodidaktika v kontextoch sprostredkovaného a zmysluplného učenia. In Duchovicova, J., Skoda, J. 2013. Psychodidaktické pojetí kulikurálniho a mediačného kontextu edukace. Ústí nad Labem : UJEP. ISBN 978-80-7414-658-9.

FLAVELL, J. H. 1979. Metakognition and cognitive monitoring. A new area of cognitive development inquiry. In American Psychologist, vol. 34, n. 8, p. $906-911$.

HACKER, D. J. - DUNLOSKY, J. - GRAESSER, A. C. 2009. Handbook of metacognition in education. New York : Rotledge. ISBN 0-8058-6353-2. HNILICA, K. 1992. Kognitivni a metakognitivni strategie autoregulovaneho uceni. In Pedagogika, vol. 42, n. 4, pp. 477-485. ISSN 0031-3815.

MARES, J. 1998. Styly uceni zaku a studentu. Prague: Portal. ISBN 807178-246-7.

SIMONS, P. R. J. 1994. Metacognitive strategies - Teaching and testing for. In: International encyclopedia of education. Oxford, Elsevier Science, s. 3788-3792. [cit. 2010/19/12] Available online: http://igiturarchive.library.uu.nl/ivlos/2005-0622- 190116/5831.pdf

SIMONS, P. R. J. 1994. Metacognition. In: International encyclopedia of education. Oxford, Elsevier Science, s. 3784-3788. [cit. 2010/19/12] Available online: http://igitur-archive.library.uu.nl/ivlos/2005-0622190116/5831.pdf

SKODA, J. - DOULIK, P. 2011. Psychodidaktika. Metody efektivného a smysluplneho uceni a vyucovani. Prague: Grada. ISBN 978-80-247-33418. 
VAGNEROVA, M. 2001. Kognitivna a socialna psychologie skolniho zaka. Prague: Karolinum. ISBN 80-246-0181-8.

VYROSTEKOVA, K. 2012. Modifikacia vyucovacich strategii zameranych na ucebnu cinnost ziakov. Doctoral thesis. Nitra: PF UKF.

ZIMMERMAN, B. J. 1998. Developing Self-Fulfiling Cycles of Academic Reagulation: An Analysis of Exemplary Instructional Models. In Zimmerman, B., J., Schunk, D., H. Self-Regulated Learning - From Teaching to Self-Reflective Practice. New York : Guilford Press, pp. 1-19, ISBN 1-57230-306-9.

doc. PaedDr. Juraj Komora, PhD.

PaedDr. Katarína Vyrosteková, PhD.

Department of Education

Faculty of Education

Constantine the Philosopher University

Dražovská cesta 4, 94974 Nitra

Slovakia

jkomora@ukf.sk

kvyrostekova@ukf.sk 